Anuario Latinoamericano Ciencias Políticas

y Relaciones Internacionales

vol. 10,2020

pp. 39-54

\section{Reshaping the International Economic Order. China's Belt and Road Initiative}

DOI:10.17951/al.2020.10.39-54

\section{Remodelando el orden económico internacional: la iniciativa china de la Franja y la Ruta}

\author{
David Garciandía Igal * \\ DEPARTMENT OF POLITICS AND INTERNATIONAL STUDIES \\ ST. JOHN'S COLLEGE, UNIVERSITY OF CAMBRIDGE \\ UNITED KINGDOM \\ $\triangle$ dg584@cam.ac.uk \\ https://orcid.org/0000-0002-0637-6397
}

\begin{abstract}
The Belt and Road Initiative is the most ambitious infrastructure development project in recent history. It is an important factor in China's rise equation. However, despite its geoeconomic starting point, the project has profound global implications. The aim of this study is to analyse three basic questions: 1) What is it? 2) How is it financed? 3) Why was it launched? In answering these questions, I argue that the New Silk Road may represent a means for China to influence the established international economic order.
\end{abstract}

KEYWORDS: Belt and Road Initiative, One Belt One Road, China, international economic order, geoeconomics.

\section{RESUMEN}

La Iniciativa de la Franja y la Ruta es el proyecto de desarrollo de infraestructuras más ambicioso en la historia reciente. Supone un importante factor en la ecuación del ascenso de China. Sin embargo, pese a que tiene un principio geoeconómico, el proyecto conlleva profundas implicaciones globales. El objetivo de este estudio es analizar tres preguntas básicas: 1) ¿Qué es? 2) ¿Cómo está financiado? 3) ¿Por qué se lanzó? Al responder a estas preguntas, sostengo que la Nueva Ruta de la Seda puede representar un medio para que China influya en el orden económico internacional establecido.

PALABRAS CLAVE: Iniciativa de la Franja y la Ruta, Nueva Ruta de la Seda, China, orden económico internacional, geoeconomía.

* M. Phil. in Politics and International Studies student at the University of Cambridge funded with a Ramón Areces full scholarship. Graduate in Laws (LL.B.) and Business Administration (B.B.A.) from the Public University of Navarre (Spain). Main research interests: promotion of human rights, especially freedom of religion, and the global politics of China. Founder of an NGO that promotes Sino-Spanish relations. He has worked for the Permanent Mission of Spain to the United Nations in Vienna. 
Dossier América Latina: la iniciativa china de la Franja y la Ruta

\section{Introduction}

The international economic order established by the United States (as well as Europe and Japan to a lesser extent) after World War II relies on different international organizations such as the International Monetary Fund, the World Bank, or the World Trade Organization. However, the rise of China is a disruptive element in this equation. A trend that has been exacerbated after President Xi Jinping launched in 2013 the Belt and Road Initiative (BRI). The initiative, and its surrounding institutions, is one of the most ambitious infrastructure projects in recent history and is called upon to transform the world as we know it.

Although the BRI has a geoeconomic starting point, there are geopolitical implications for the regional and the global order that should not be overlooked. The Belt and Road Initiative is much more than just a mere trade policy. In this regard, the goal of the paper is to respond to three key questions. First of all: 1) What is the BRI and its sphere of influence? To answer this question, the paper gives an overview of the history of the Silk Route and examines the project from a descriptive viewpoint. The second section concerns financing: 2) How is the BRI financed and how does the project fit into the existing gap in infrastructure investment in Asia? The last part refers to the motivations behind the BRI: 3) Why did the Chinese Government launch the BRI?

Under the descriptive method, an extensive review of academic research, political official discourses, Chinese Government White Papers, specialized press, and reports from international organisations and foundations, has been conducted. This analysis of pre-existing literature allows the researcher to construct qualitative arguments, illustrated in some cases by a quantitative analysis of existing data provided by international organizations, private companies, and other international entities.

\section{What is the Belt and Road Initiative?}

The Silk Route was a network of trade routes that connected the East and the West. It started in China (in what is now Xian), and extended through Mongolia, India, Persia, Arabia, Syria, Turkey, Europe, and Africa. Silk trade was its main raison d'être, although many other textiles, spices or art crafts were traded as well. However, not only was it a trade route but an important communication channel for ideas, spiritual messages, technologies, or sciences (Hansen, 2015).

Numerous names have been given to this network of routes within the past centuries. "Samarkand Route" or "North and South Route" might be the most well-known ones. However, nowadays the most used name is the term "Silk Road" coined in 1877 by Ferdinand von Richthofen, German geographer and traveller. As far as origins of this route are concerned, there is evidence of the 
existence of the Silk Route since the Han Dynasty (206-220 BC), although it is commonly related with the Tang Dynasty (618-907 AD). These economic, cultural, political, and religious interactions lasted until the $18^{\text {th }}$ century. The Silk Route then entered a period of decline. Nevertheless, it has flourished again in the $21^{\text {st }}$ century (Hansen, 2015).

In the past decades or so, China has not been the only one interested in digging up the Silk Road notion. This idea has remained in several countries' psyche since the old project disappeared. Japan introduced the concept of "Silk Road Diplomacy" in 1997, to strengthen relations with different regions in Central Asia. In relation to the US presence in Afghanistan, the American Government launched in 2011 a "New Silk Road" initiative. Its main aim was to integrate the South Asian country with other regions "by resuming traditional trading routes and reconstructing significant infrastructure links broken by decades of conflict" (US Department of State, 2017). As we can see, the idea is not new. However, the magnitude and nature of the project could not be more different.

The new and ambitious China's Belt and Road Initiative (also called "One Belt, One Road" or "New Silk Road") was raised for the first time by President $\mathrm{Xi}$ Jinping in a speech titled "Promote People-to-People Friendship and Create a Better Future”, at Kazakhstan's Nazarbayev University on 7 September 2013. The project, according to the President's view, aims to step forward the Chinese economy, connecting different economic areas and promoting China's presence in the world scenario. Nevertheless, concerns have been raised in the international community due to the extent, possible implications, and real motivations behind the project.

The number of partners adhering to this initiative is rapidly increasing. In April 2019, there were 125 countries and 29 international organizations involved, whereas in November 2019 China already had cooperation agreements with 137 countries and 30 international organizations ${ }^{1}$ (State Information Center, 2019). This represents more than $70 \%$ of the world's population, above $55 \%$ of global GNP (Pu, 2016, p. 113) and about 75\% of known energy reserves (Hilton, 2019).

From 2013 to 2018, the trade volume of goods between the BRI countries and China surpassed 6 trillion US dollars. In fact, between January 2019 and September 2019, China's trade with the BRI countries totalled about 950 billion US dollars, and its non-financial direct investment in these countries topped 10 billion US dollars. Additionally, China arranged bilateral currency swap accords with 20 countries and established RMB clearing arrangements with seven countries (State Information Center, 2019).

The BRI has been compared with the Marshall Plan, although the magnitude of the Chinese project is much larger, as evidenced by these num-

1 Xi Jinping's remarks on November 5, 2019 in the opening speech at the China International Import Expo in Shanghai.
Reshaping

the International

Economic Order. China's

Belt and Road Initiative

David Garciandía Igal 
Dossier América Latina: la iniciativa china de la Franja y la Ruta bers. Moreover, the BRI differs from the Marshall Plan in its motivation and possible global implications. Under the Marshall Plan, the US and the UK sought, among others, geopolitical goals (such as to prevent the spread of communism), whereas the Chinese Government, at least in its official discourse, wants to promote economic prosperity and peace, regardless of political aims. According to this official narrative, the starting point for the BRI is more geoeconomic than geopolitical ${ }^{2}$ (Callahan, 2016, p. 11). Furthermore, the challenges of the BRI to be faced outnumber those of the Marshall Plan, as explained below.

Whereas "the Belt" refers to the Silk Road Economic Belt, "the Road" refers to the $21^{\text {st }}$-century Maritime Silk Road. The Belt is focused on inland projects, knitting together China, Central Asia, Russia, and Europe. On the other hand, The Road aims to connect China's coast with Europe through the South China Sea and the Indian Ocean; and to connect China's coast with the South Pacific through the South China Sea (see Figure 1). Some of the countries involved are emerging countries with high development potential, while others are developed countries with strong industries, minerals, energy, or tourism.

Despite the names given, the distinction between the Belt and the Road is not the key point. The difference is symbolic, just a matter of names. The important difference is that, while the inland initiative relies on international transport routes (taking advantage of core cities and key economic industrial parks), oil and natural gas pipelines and power grids, the maritime initiative is focused on building smooth, secure and efficient transport routes connecting significant seaports and other coastal infrastructure projects (National Development and Reform Comission, 2015). The difficulties for coordinating such a diverse initiative with so different States are tremendous.

The land-based part of the BRI is being carried out through six economic corridors $^{3}$ that embrace different inland areas of Europe and Asia. The seabased part of the BRI entails a maritime route, which seeks to connect Europe, Africa, and Asia through the sea. In addition, in January 2018 the Chinese Government issued a White Paper titled "China's Arctic Policy". The aim of this document is to guide China's action in Arctic affairs. However, this blueprint also announced the development of a "Polar Silk Road" under the BRI, due to the special geographical location of the Arctic and its natural environment and rich resources (State Council Information Office of the People's Republic

2 According to Yu (2017, p. 354), "geopolitics studies the influence of aspects as military, political, human resources and other hard power elements on the policy of a State, particularly its foreign policy. Meanwhile, geoeconomics focuses more on economic space, covering transportation connectivity, networks, commerce, trade, investment, and financial and economic strengths".

3 New Eurasian Land Bridge Economic Corridor, China-Mongolia-Russia Economic Corridor, China-Central Asia-West Asia Economic Corridor, China-Indochina Peninsula Economic Corridor, China-Pakistan Economic Corridor, Bangladesh-China-India-Myanmar Economic Corridor. 


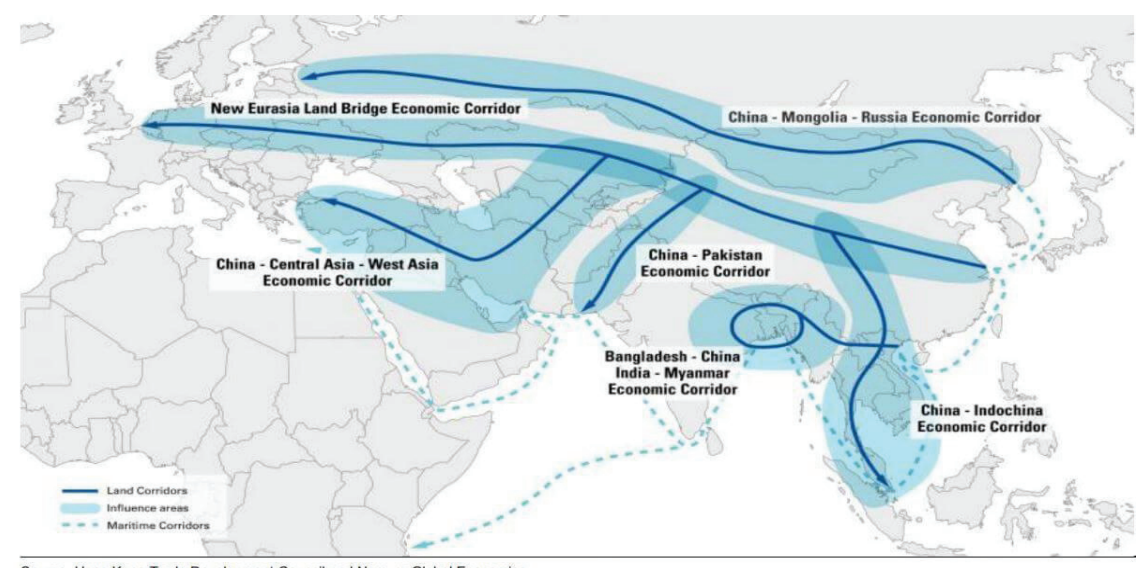

Source: Hong Kong Trade Development Council and Nomura Global Economics.

Source: Hong Kong Trade Development Council and Nomura Global Economics (retrieved from https:/www.nomuraconnects.com/focused-thinking-posts/the-belt-and-road-initiativeglobalisation-china-style/).

of China, 2018). Consequently, there are six economic land corridors and two maritime routes.

Numerous projects are being developed through these economic corridors and the maritime route. In December 2019, more than 100 initiatives were registered, such as oil and natural gas pipelines, high-speed railways (both freight and passenger trains), airports, seaports, or industrial parks. These projects are held in partner countries around Europe, Africa, and Asia (Hielscher \& Ibold, 2019). The pipelines used for transmission of mobile phone and Internet data will be particularly important in the years to come, especially in view of the restrictions imposed by the coronavirus situation, such as lockdowns or teleworking (Caro, 2020).

In this sense, the signing of the cooperation agreement with Italy in March 2019 is especially important. It is the first G-7 country that joins the BRI, and the agreement has a deep symbolic value considering the reticence shown by some Western countries regarding geostrategic concerns. Whereas Italy has a huge need of investment and financing, China sees Italian ports as perfect places to distribute its products.

\section{How is the Belt and Road Initiative financed? The gap in infrastructure investment in Asia}

Almost nobody would contest the fact that a smart investment in infrastructure is a crucial economic driver to develop a country's economy and eradicate poverty (Ali \& Pernia, 2003, p. 9). Its importance is especially
Reshaping

the International

Economic Order. China's

Belt and Road Initiative

David Garciandía Igal

Figure 1.

Map of the six economic corridors of the Belt and Road Initiative 
Dossier América Latina: la iniciativa china de la Franja y la Ruta

Figure 2.

Estimated Infrastructure Investment Needs by Region high for overcoming geographical issues and reducing the high costs of production in landlocked countries ( $\mathrm{Yu}, 2017$, p. 357). In this sense, in Asia there is a gap of infrastructure investment of \$26 trillion from 2016 to 2030 (see Figures 2 and 3) if the region is to maintain its growth momentum, eradicate poverty and respond to climate change ${ }^{4}$ (Asian Development Bank, 2017, p. 11).

\begin{tabular}{|c|c|c|c|c|c|c|c|c|c|}
\hline \multicolumn{10}{|c|}{ Estimated Infrastructure Investment Needs by Region 2016-2030 ( $\$$ billion in 2015 prices) } \\
\hline \multirow[t]{2}{*}{$\begin{array}{l}\text { Region/Sub- } \\
\text { region }\end{array}$} & \multirow{2}{*}{$\begin{array}{l}\text { Pro- } \\
\text { jected } \\
\text { Annual } \\
\text { GDP } \\
\text { Growth }\end{array}$} & \multirow{2}{*}{$\begin{array}{l}2030 \text { UN } \\
\text { Popula- } \\
\text { tion Pro- } \\
\text { jection } \\
\text { (billion) }\end{array}$} & \multirow{2}{*}{$\begin{array}{l}2030 \\
\text { Projected } \\
\text { GDP Per } \\
\text { Capita } \\
(2015 \$)\end{array}$} & \multicolumn{3}{|c|}{ Baseline Estimates } & \multicolumn{3}{|c|}{$\begin{array}{l}\text { Climate-adjusted Esti- } \\
\text { mates }^{* *}\end{array}$} \\
\hline & & & & $\begin{array}{l}\text { Invest- } \\
\text { ment } \\
\text { Needs }\end{array}$ & $\begin{array}{l}\text { Annual } \\
\text { Average }\end{array}$ & $\begin{array}{l}\text { Invest- } \\
\text { ment } \\
\text { Needs } \\
\text { as } \% \\
\text { of GDP }\end{array}$ & $\begin{array}{l}\text { Invest- } \\
\text { ment } \\
\text { Needs }\end{array}$ & $\begin{array}{l}\text { Annual } \\
\text { Average }\end{array}$ & $\begin{array}{l}\text { Invest- } \\
\text { ment } \\
\text { Needs } \\
\text { as \% } \\
\text { of } \\
\text { GDP }\end{array}$ \\
\hline Central Asia & 3.1 & 0.096 & 6,202 & 492 & 33 & 6.8 & 565 & 38 & 7.8 \\
\hline East Asia & 5.1 & 1.503 & 18,602 & 13,781 & 919 & 4.5 & 16,062 & 1,071 & 5.2 \\
\hline South Asia* & 6.5 & 2.059 & 3,446 & 5,477 & 365 & 7.6 & 6,347 & 423 & 8.8 \\
\hline $\begin{array}{l}\text { Southeast } \\
\text { Asia }\end{array}$ & 5.1 & 0.723 & 7,040 & 2,759 & 184 & 5.0 & 3,147 & 210 & 5.7 \\
\hline The Pacific & 3.1 & 0.014 & 2,889 & 42 & 2.8 & 8.2 & 46 & 3.1 & 9.1 \\
\hline $\begin{array}{l}\text { Asia and the } \\
\text { Pacific }\end{array}$ & 5.3 & 4.396 & 9,277 & 22,551 & 1,503 & 5.1 & 26,166 & 1,744 & 5.9 \\
\hline
\end{tabular}

Note: ${ }^{*}$ Pakistan and Afghanistan are included in South Asia. ${ }^{*}$ Climate change adjusted figures include climate mitigation and climate proofing costs, but do not include other adaptation costs, especially those associated with sea level rise.

Source: recovered by the author from (Asian Development Bank, 2017).

The cited Asian Development Bank study analyses four different sectors: power, transport, telecommunications, and water and sanitation. All these areas are covered by the BRI, specially the first three. As we can observe in the tables, East Asia (China, Japan, Mongolia, North Korea, South Korea, and Taiwan) needs the largest investment in infrastructure, with energy being the most deficient sector in terms of lack of investment.

In this regard, the BRI could prove to be the solution, at least partially, to these infrastructure needs. The whole initiative is estimated in 4-8 trillion US dollars (Hielscher \& Ibold, 2019). For this reason, several funding channels are needed: BRI bonds, private capital investment, Public-Private Partnerships

4 The need would be of $\$ 22.6$ trillion without climate change mitigation and adaptation costs. 


\begin{tabular}{|c|c|c|c|c|c|c|c|c|}
\hline \multicolumn{9}{|c|}{ Estimated Infrastructure Investment Needs by Sector 2016-2030 ( $\$$ billion in 2015 prices) } \\
\hline \multirow{2}{*}{ Sector } & \multicolumn{3}{|c|}{ Baseline Estimates } & \multicolumn{3}{|c|}{ Climate-adjusted Estimates } & \multicolumn{2}{|c|}{$\begin{array}{l}\text { Climate-related } \\
\text { Investments } \\
\text { (Annual) }\end{array}$} \\
\hline & $\begin{array}{l}\text { Investment } \\
\text { Needs }\end{array}$ & $\begin{array}{l}\text { Annual } \\
\text { Average }\end{array}$ & $\begin{array}{l}\text { Share of } \\
\text { Total }\end{array}$ & $\begin{array}{l}\text { Investment } \\
\text { Needs }\end{array}$ & $\begin{array}{l}\text { Annual } \\
\text { Average }\end{array}$ & $\begin{array}{l}\text { Share } \\
\text { of } \\
\text { Total }\end{array}$ & $\begin{array}{l}\text { Adap- } \\
\text { tation }\end{array}$ & $\begin{array}{l}\text { Mitiga- } \\
\text { tion }\end{array}$ \\
\hline Power & 11,689 & 779 & 51.8 & 14,731 & 982 & 56.3 & 3 & 200 \\
\hline Transport & 7,796 & 520 & 34.6 & 8,353 & 557 & 31.9 & 37 & - \\
\hline $\begin{array}{l}\text { Telecommu- } \\
\text { nications }\end{array}$ & 2,279 & 152 & 10.1 & 2,279 & 152 & 8.7 & - & - \\
\hline $\begin{array}{l}\text { Water and } \\
\text { Sanitation }\end{array}$ & 787 & 52 & 3.5 & 802 & 53 & 3.1 & 1 & - \\
\hline Total & 22,551 & 1,503 & 100.0 & 26,166 & 1,744 & 100.0 & 41 & 200 \\
\hline
\end{tabular}

Reshaping

the International

Economic Order. China's

Belt and Road Initiative

David Garciandía Igal

\section{Figure 3.}

Estimated Infrastructure Investment Needs by Sector

Note: ${ }^{*}$ Denotes not applicable.

Source: Recovered by the author from (Asian Development Bank, 2017).

\begin{tabular}{llll}
\hline State-Owned Banks & Policy Banks & $\begin{array}{l}\text { International Financing } \\
\text { Institutions }\end{array}$ & State-Owned Funds \\
\hline $\begin{array}{l}\text { Agricultural Bank } \\
\text { of China }\end{array}$ & $\begin{array}{l}\text { Agricultural } \\
\text { Development Bank } \\
\text { of China }\end{array}$ & Asian Development Bank & $\begin{array}{l}\text { China Investment } \\
\text { Corporation }\end{array}$ \\
\hline Bank of China & $\begin{array}{l}\text { China Development } \\
\text { Bank }\end{array}$ & $\begin{array}{l}\text { Asian Infrastructure } \\
\text { Investment Bank }\end{array}$ & Silk Road Fund \\
\hline $\begin{array}{l}\text { China Construction } \\
\text { Bank }\end{array}$ & $\begin{array}{l}\text { Export-Import Bank } \\
\text { of China }\end{array}$ & New Development Bank & \\
\hline $\begin{array}{l}\text { Industrial and } \\
\text { Commercial Bank } \\
\text { of China }\end{array}$ & & & \\
\hline
\end{tabular}

Source: Recovered by the author from different sources.

(PPP) or State-Owned Enterprise investment (SOE), among others. In connection to these channels, numerous institutional mechanisms are taking part in the BRI. The most remarkable ones are represented in Figure 4.

Among them, the Asian Infrastructure Investment Bank (AIIB) and the Silk Road Fund (SRF) are of particular relevance due to their ad hoc creation. On the one hand, the AIIB was announced in 2013, during Xi Jinping's state visit in Jakarta (Indonesia). Finally, it was officially launched in 2014, and began operating in 2016 with a capital of $\$ 100$ billion $^{5}$. Its main aim is to support

5 Which represents 2/3 of the capital of the Asian Development Bank and about 1/2 that of the World Bank.

Figure 4.

Institutions involved in financing the Belt and Road Initiative 
Dossier América Latina: la iniciativa china de la Franja y la Ruta the building of infrastructures in the Asia-Pacific region with a green approach. One positive impact of this new bank is that is has placed infrastructure at the centre of development finance regimes (Gabusi, 2017, p. 40). This new institution seeks to cooperate rather than to compete with other financing sources, such as the Asian Development Bank (ADB), of which China is a member along with other Asian and Western countries ${ }^{6}$. This is the case of developed countries such as the UK (with a subscription of $\$ 3,054$ million and 2.91\% of voting power in the AIIB), Germany ( $\$ 4,484$ million and $4.18 \%)$, France (\$3,376 million and 3.20\%), Italy ( $\$ 2,572$ million and $2.49 \%)$ or Spain $(\$ 1,761$ million and $1.77 \%$ ). All of them joined the AIIB in recent years, participating in the new international financial architecture.

As some authors argue, China is following two strategies to reform the existing global financial system. Firstly, it is working together with emerging countries such as the BRICS (Brazil, Russia, India, China, and South Africa), that share the perception of being underrepresented in the financial international system designed by the West, to achieve reforms. The second strategic line is to take steps in order to create new financial institutions, such as the case of the AIIB. By doing this, "China is putting more pressure on the West to accelerate the process of international financial reforms by challenging the dominant role of the World Bank and the ADB in funding transportation and other infrastructure projects in Asia" (Yu, 2017, p. 360).

With the establishment of the AIIB, China has strengthened its leadership and influence in the regional governance. However, this new institution has imitated some of the Western system imperfections. This is the case of the veto power, that causes many troubles in the bosom of the United Nations Security Council. Although the Articles of Agreement of the bank do not include this possibility, they establish a requirement of at least $75 \%$ of total votes in order to amend the text, adjust the capital shares of regional members, increase the capital base of the bank and make other major changes. China, that is the largest shareholder, holds a total voting share of over $26 \%$, due to its contribution of almost $\$ 29.78$ billion. Consequently, China has de facto veto power in the AIIB (Yu, 2017, p. 359).

On the other hand, the Silk Road Fund is a state-owned investment fund with limited liability that was established in December 2014 by the Chinese Government. Its main goal is to foster investment in BRI's projects along partner States. China pledged $\$ 40$ billion as the initial investment for the constitution of the fund. The SRF has four main shareholders: The State Administration of Foreign Affairs (65\%), the China Investment Corporation (15\%), the Export-Import Bank of China (15\%) and the China Development Bank (5\%). It represents another international institution that is under Chinese control and that has an important impact on the region. Both the AIIB and the SRF

6 Both the Chinese President Xi Jinping and the ADB Chief Takehiko Nakao have expressed similar views on this cooperation will. 
provide a channel for investment of Chinese capital in other countries, helping to diversify its energy and raw materials supply overseas and safeguard its national energy and economic security (Yu, 2017, p. 360).

\section{Why was the Belt and Road Initiative launched?}

Much has been written regarding the debate about whether the nature of the BRI is geopolitical or geoeconomic. In the official discourse, there is no doubt that the starting point is economic. Since the 2008 financial crisis, the Chinese economy has entered a new period. It is facing different challenges and obstacles and it should find a new "engine for economic growth". Efforts are focused on diversifying its economy, embracing a more sustainable level of growth, and distributing benefits more equally. The Chinese Government is taking measures in order to transform the "low-end, export-driven model into a more sustainable and innovative economy" ( $\mathrm{Pu}, 2016$, p. 114). However, trade remains a crucial driver for the Chinese economy and it seems that in the short-term it will continue to be so. As evidence points out, China is the largest exporting country in absolute terms in 2019 (see Figure 4), overcoming the US, Germany, or Japan.

However, China's dependency on trade is not as large as some may think. We could measure this dependency through two different indicators. The first way is to look at China's export dependency (measured by percentage of GDP that exports of goods and services represent, see Figure 5) and import dependency (measured by percentage of GDP that imports of goods and services re-

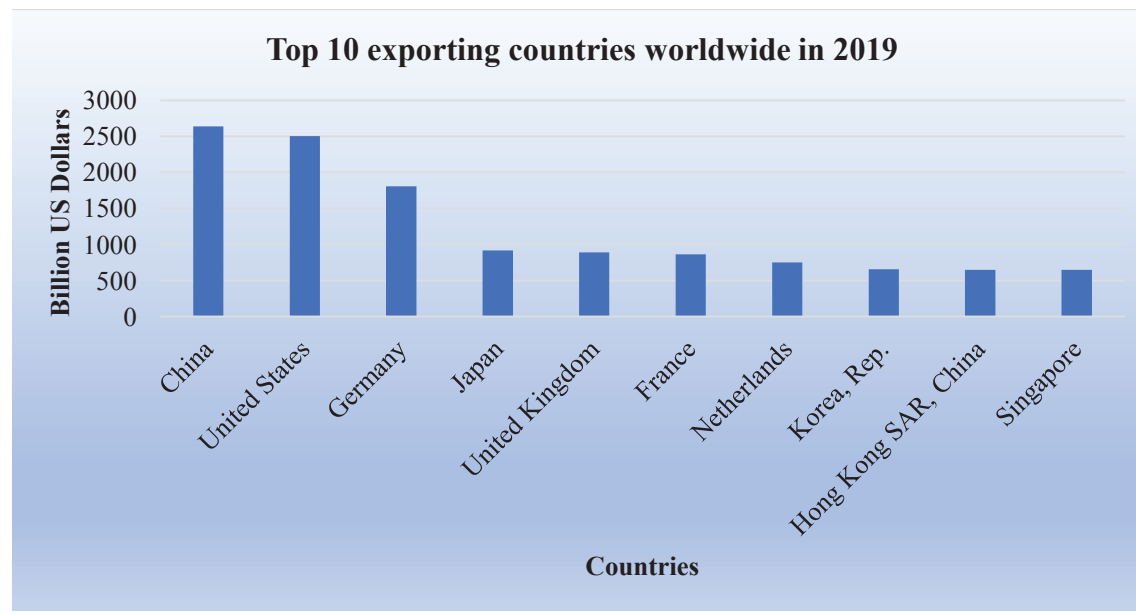

Note: * Data for Japan is for 2018 , as the World Bank has not yet provided official data for 2019 at the time of writing this paper.

Source: Compiled by the author based on data supplied by the World Bank.
Reshaping

the International

Economic Order. China's

Belt and Road Initiative

David Garciandía Igal

\section{Figure 5.}

Top 10 exporting countries worldwide in 2019 
Dossier América Latina: la iniciativa china de la Franja y la Ruta

Figure 6.

Exports of goods and services as percentage of GDP

Figure 7.

Imports of goods and services as percentage of GDP present, see Figure 6). In both cases, we observe that China is below the world average. Although its average is higher than that of the US, it is lower than those of other Western countries such as Germany or the United Kingdom.

The other way to measure China's dependency on trade is through its "trade openness" (sum of exports plus imports as percentage of GDP). By the same token, China's percentage in 2019 was above that of the US (according to the World Bank, 35.68\% vs. $26.39 \%$, respectively), although lower than the world average $(60.40 \%)$ and that of some European countries such as Germany $(88.10 \%)$ or the United Kingdom $(64.25 \%)$. In this context, some studies highlight that the world's relative exposure to China has increased, while China's to the world has fallen (McKinsey Global Institute, 2019, p. 3).

\section{Exports of goods and services as percentage of GDP}

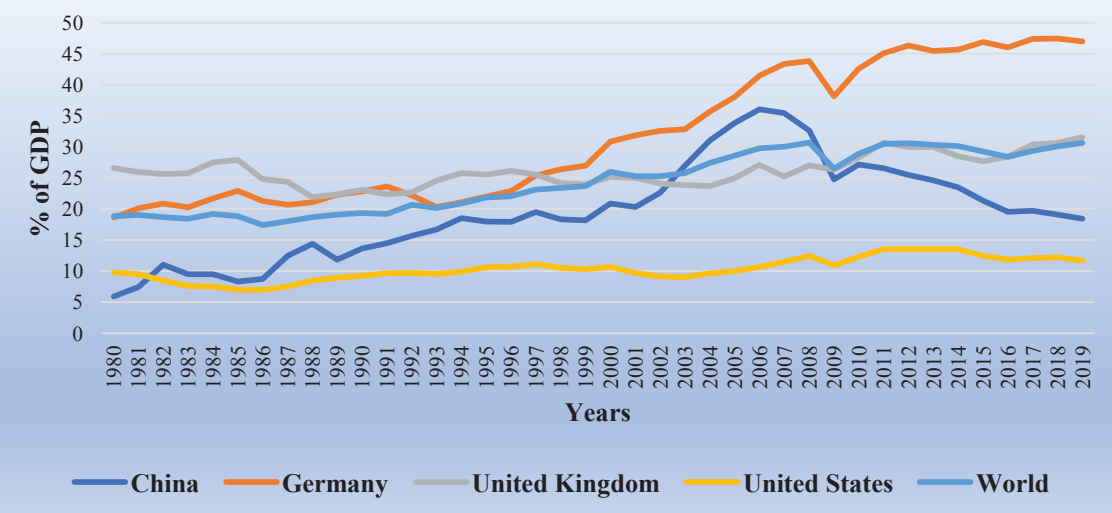

Source: Compiled by the author based on data supplied by the World Bank.

Imports of goods and services as percentage of GDP

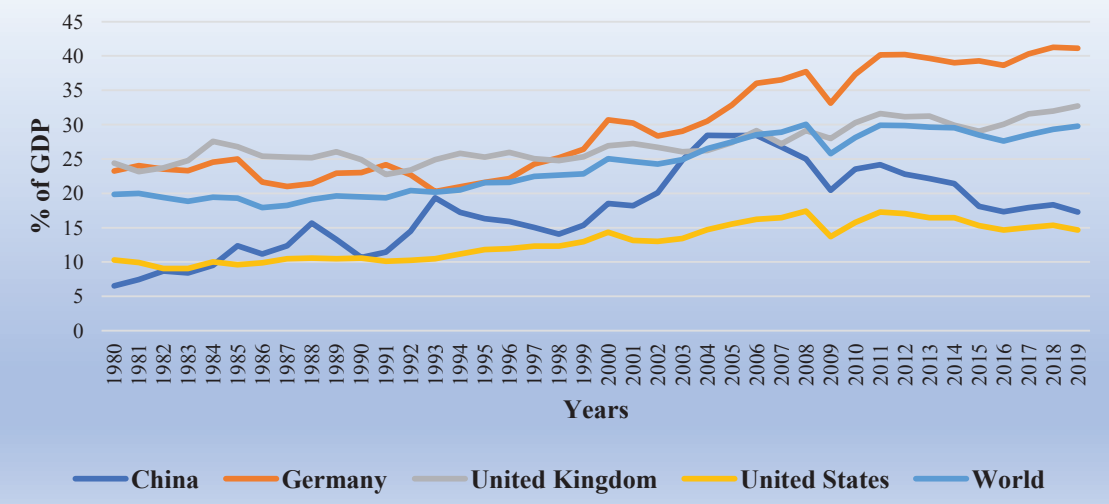

Source: Compiled by the author based on data supplied by the World Bank. 
This is precisely one of the main motivations of China behind the Belt and Road Initiative - to address the overcapacity problem of some economic sectors. The official political discourse of the Chinese Government outlines this point. One of the main goals of the BRI is to promote global trade and to strengthen economic cooperation between countries (National Development and Reform Comission, 2015). Geopolitical considerations aside, it is obvious that improving trade is considered part of the solution to this problem, since this would allow Chinese companies to sell products and services to other countries, reducing the excess of capacity. Concerns about China's overcapacity in several industries have been raised all around the world. As evidence points out, excessive capacity in the coal industry is a deep problem (Zhang, Zhang, Liu, \& Nie, 2017). The following quote is very representative about the relation between the BRI and the overcapacity problem:

The implementation of a new Silk Road strategy will help to revive China's slowing domestic economy by boosting foreign trade and China's outward investment. This strategy will also allow China more time and room for pursuing industrial restructuring and upgrading. The slowdown in the Chinese economy has resulted in a serious problem of domestic production overcapacity in China's heavy industries. Participating in the infrastructure projects financed by the AIIB will help to absorb China's massive production overcapacity at home in manufacturing, infrastructure construction and related industries. (Yu, 2017, pp. 360-361)

Nonetheless, some economists are sceptical about the efficiency of the BRI in mitigating this issue. In relation to the steel industry, for example, some authors estimate that the BRI might absorb “only" around 7\% of China's overcapacity (Yu, 2017, p. 358). In this regard, the BRI effects on solving this problem could be limited.

In addition to this, another economic motivation is the internationalization of the Renminbi (RMB). This is one of the main strategic lines of the Chinese Government. It is not something new that stems from the BRI, but a previous priority that is now backed by this initiative. The Renminbi is the eighth most used currency in the world nowadays, with $4.3 \%$ shares of average daily turnover in April 2019 (Bank of International Settlements, 2019, p. 3). Accordingly, the BRI seeks to increase popularity of the currency use in international transactions, increasing especially the liquidity of offshore RMB use. It is clear that the ease of paying and trading in Renminbi on the BRI routes would help to achieve this goal (Liu, 2015). Efforts should be made to "lower transaction costs, so as to increase the share of RMB in trade, investment, and foreign exchange reserve, which will inject momentum to make RMB an important international currency" (Pu, 2016, p. 114).

However, the People's Bank of China does not try to establish the RMB only as a global trade currency, but also as a global investment and reserve currency
Reshaping the International Economic Order. China's Belt and Road Initiative

David Garciandía Igal 
Dossier América Latina: la iniciativa china de la Franja y la Ruta
(Bowles \& Wang, 2013). Currently, China is a net capital exporter, and bearing in mind the BRI and the “Go Out policy" (走出去战略) of Chinese companies, the internationalization of the RMB is likely to be strengthened during the next few years. Although the effects on the international financial global order are difficult to gauge, some experts have argued that if there is to be a shift in the dominant reserve from the US Dollar to another currency in the next decades, that one would be the Chinese Renminbi (Subramanian, 2011, p. 22).

Despite this bright future, threats lurk for the RMB. In this sense, Barry Eichengreen and Masahiro Kawai argue that:

A high degree of $R M B$ internationalisation requires significant capital account liberalization, [...] which in turn would call for greater exchange rate flexibility so that the People's Bank of China can enjoy monetary policy autonomy. This, however, would pose a challenge for the PRC authorities as hasty capital account liberalization could expose PRC financial markets to the risk of crisis. (Eichengreen \& Kawai, 2014, p. 2)

Improving China's energy security is another motivation behind the BRI. The economic growth of the Asian country over the last years has relied on energy imports, especially crude oil and natural gas (Wuthnow, 2017, p. 11). Due to this fact, piracy is a threat for Chinese energy shipments, especially in the Malacca Strait, were $80 \%$ of Chinese oil imports flow (U.S. Energy Information Administration, 2015). In this sense, port construction in the Indian Ocean would bring new secure maritime routes for China, as well as constructing overland pipelines. These measures would avoid China's dependence on the Strait of Malacca and would improve the time and security of China's energy imports (Wuthnow, 2017, p. 11).

From a domestic point of view, another motivation is the rebalance of regional development inside China. Since the opening process in the Chinese economy and the establishment of Special Economic Zones, the Western Chinese regions are suffering a lack of infrastructure and strong trade routes that connect them with the coastal developed regions. During decades, technology was developed, and investment placed, on the Eastern regions. The Western regions are isolated in terms of efficient connectivity and economic equity. This situation has led to deep interprovincial inequalities (Liao \& Wei, 2016, p. 5).

In order to manage this grave problem, the Chinese Government has been developing regional programs such as “Western Development" (西部大开 发), “Revitalize the Northeast Industrial Bases” (振兴东北老工业基地) or “Rise of Central China Plan" (中部崛起计划). In this regard, the BRI could be a linkage between all these regional programs and, undoubtedly, represents the most ambitious plan for the development of the Western Chinese regions. This is especially important in the case of Xinjiang. Through development and prosperity in that region, the separatist tendencies of the Uighur minority could be reduced. As it has been stated, poverty is one of the main roots of te- 
rrorism and extremism (Haiyun, 2015, pp. 13-22). This could lead to stability in the region and could prove to be an example to other regions such as Tibet, were similar territorial claims are held.

In addition, it must be said that the idea of the Silk Road has a strong romantic component. In the Chinese culture, this concept has a strong sense of "Chineseness". It is conceived as something inherent to their civilization and their values. The use of this concept is, therefore, linked to a nationalist idea that would help, among other things, to strengthen China's unity.

The last type of motivation behind the BRI is of a diplomatic nature. The project fits into the framework of the new proactive foreign policy of China. It is clear that $\mathrm{Xi}$ Jinping has established close ties with countries such as Kazakhstan, Kyrgyzstan or Tajikistan. But the so-called "peripheral diplomacy" (Swaine, 2014), in which the BRI suits, extends far beyond. The influence of China in other countries of Asia and even Africa or Europe is becoming higher. China, through the above-mentioned financial institutions, is lending large amounts of financial resources. As a consequence, the Asian country owns massive amounts of public and private debt from other countries, with the power of control this fact entails. Under the "win-win cooperation" approach for international relations fostered by the Chinese Government, China is creating a new regional order. It has integrated development, security, and institution-building in order to forge a new network with China in the epicentre (Callahan, 2016, p. 13). The expansion of its strategic influence, while avoiding a direct crash with the United States, seems to be another crucial driver in the BRI (Wuthnow, 2017, p. 8).

Nevertheless, it is true that many risks and uncertainties in the horizon have been pointed out by experts. First of all, there are economic issues: credit risk from developing countries, macroeconomic risks, legal uncertainty, regulatory risks, or poor governance and corruption in partner states. On the geopolitical side, several security issues could be found such the fact that "Chinese workers and investments could be subject to regional conflict as well as transnational challenges such as terrorism and piracy" (Wuthnow, 2017, p. 3). Additionally, some powers (for example the United States or Japan) "could oppose, either individually or collectively, China's endeavors in key regions" (Wuthnow, 2017, p. 13). Finally, the BRI itself is a somewhat vague project without a strong central authority that would coordinate the entire initiative. For these reasons, the success of the Belt and Road Initiative is subject to different problems, both current and foreseeable in the future.

\section{Conclusions}

With the end of the Cold War, the international system shifted from a bipolar world with two major blocks (the US leading capitalism and the USSR leading communism) to a unipolar world dominated by the West (mainly by the US).
Reshaping

the International

Economic Order. China's

Belt and Road Initiative

David Garciandía Igal 
Dossier América Latina: la iniciativa china de la Franja y la Ruta
However, in the $21^{\text {st }}$ century we are moving towards a multipolar world with different regional powers. This situation is especially noticeable in Asia, were different spheres of power converge (specially China, India, Russia, Japan, and the US).

In this regard, nobody would contest the fact that China has risen. Its economic development during the last decades has resulted in a position of influence, not only in regional terms but in world ones. It has consolidated its regional position in Asia, making a space for itself. In this sense, the Belt and Road initiative was launched in 2013 with several motivations behind. First of all, strengthening trade with other countries. This could prove to be a solution for the overcapacity issue in some economic sectors. Additionally, the BRI would help to transform China's low-end economic model to a more innovative one. Also, the internationalisation of the Renminbi and improving energy security are major priorities for the Chinese Government. From the domestic point of view, the BRI seeks to improve the development of some provinces by reducing regional disparities, and strengthen nationalism by using the BRI as a way of fighting terrorism.

Another kind of motivation, which is the most controversial one, is the expansion of the diplomatic and strategic influence. Although the starting point of the BRI is geoeconomic, undoubtedly, the project has deep global geopolitical implications. It is not just a mere trade initiative. China is creating a new structure of international organisations (such as the Asian Infrastructure Investment Bank or the Shanghai Cooperation Organisation), many of them surrounding or with links to the BRI, with its own norms and rules. Some of them are similar to those established by the liberal international order, and others are inspired by the Chinese vision of international order.

China's influence through the BRI (and through other channels) in neighbouring States has increased considerably. For example, the massive purchase of public and private debt from different countries is providing China a strong influence over their economy. Nevertheless, not only is the established order changing at a regional level, but also at a global one. China is becoming a rulemaking country instead of a rule-following one, as we can observe from the creation of different international organisations. This is having deep implications for the world in areas as different as private international law, trade and financial rules, etc.

Regarding the international system, China is following a joint strategy creating a new international architecture, and reforming (with support of underrepresented countries such as the BRICS) the existing one. Now, the debate is about whether China will follow the current liberal international system, despite reshaping some aspects of it, or it will challenge the current global order, creating a new one with Chinese ideas in the centre.

Nonetheless, the BRI still needs to face several economic and security issues and, of course, needs to face the opposition of other countries in order to succeed. All in all, it is clear that China will influence the world as we 
know now. However, to what extent China will change the world, only time will tell. In this regard, further research needs to be done in many aspects. The goal of this paper was much simpler - to provide the reader with an overview of the Belt and Road Initiative and the challenges it is going to create and face.
Reshaping

the International

Economic Order. China's

Belt and Road Initiative

David Garciandía Igal

\section{References}

Ali, I. \& Pernia, E. M. (2003). Infrastructure and Poverty Reduction - What is the Connection? Asian Development Bank, Economics and Research Department. Manila: ERD Policy Brief Series.

Asian Development Bank. (2017). Meeting Asia's Infrastructure Needs. Manila: Asian Development Bank. https://doi.org/10.22617/FLS168388-2 Bank of International Settlements. (2019). Triennial Central Bank Survey: Foreign exchange turnover in April 2019. Basel: Bank of International Settlements.

Bowles, P. \& Wang, B. (2013, November). Renminbi Internationalization: A Journey to Where? Development and Change, 44(6), pp. 1363-1385. https://doi.org/10.1111/ dech.12058

Callahan, W. A. (2016). China's "Asia Dream": The Belt Road Initiative and the new regional order. Asian Journal of Comparative Politics, pp. 226-243. https://doi. org/10.1177/2057891116647806

Caro Vargas, S. (2015). Economic Corridors in Asia: Paradigm of Integration? Bogotá: Universidad Externado de Colombia. Retrieved from https://bdigital.uexternado.edu.co/ handle/001/2784

Debin D. \& Yahua, M. (2015). One Belt and One Road: The Grand Geo-strategy of China's Rise. Geographical Research, 34(6), pp. 1005-1014. https://doi.org/10.11821/dlyj201506001

Dong, K., Sun, R., Hochman, G., \& Li, H. (2018). Energy intensity and energy conservation potential in China: A regional comparison perspective. Energy (155), pp. 782-795. https:// doi.org/10.1016/j.energy.2018.05.053

Eichengreen, B. \& Kawai, M. (2014, January). Issues for Renmimbi Internationalization: An Overview. Asian Development Bank Institute (454). https://doi.org/10.2139/ssrn.2382420

Gabusi, G. (2017). Crossing the River by Feeling the Gold: The Asian Infrastructure Investment Bank and the Financial Support to the Belt and Road Initiative. China \& World Economy, 25(5), pp. 23-45. https://doi.org/10.1111/cwe.12212

Haiyun, W. (2015). Geostrategic Thinking of Belt and Road Initiative. International Strategic Studies (3), pp. 13-22.

Hansen, V. (2015). Silk Road. A New History. New York City: Oxford University Press. https://doi.org/10.1111/hisn.12054_34

Hielscher, L. \& Ibold, S. (2019, June 17). Belt and Road Initiative. Belt and Road Initiative: Retrieved March 2020, from https://www.beltroad-initiative.com/info/

Hilton, I. (2019, January 3). How China's Big Overseas Initiative Threatens Global Climate Progress. Yale Envrionment 360. Retrieved February 2020, from https://e360.yale.edu/ features/how-chinas-big-overseas-initiative-threatens-climate-progress 
Dossier América Latina: la iniciativa china de la Franja y la Ruta
Liao, F. H. \& Wei, Y. D. (2016, September). Sixty Years of Regional Inequality in China: Trends, Scales and Mechanisms. RIMISP Working Paper Series (202), pp. 1-20.

Liu, C. (2015, November 2). Chinese OBOR - linked investments to boost RMB internationalization. China Daily. Retrieved February 2020, from http://www.chinadaily. com.cn/world/2015-11/02/content_22350361.htm

McKinsey Global Institute. (2019). China and the World: Inside the Dynamics of a Changing Relationship. McKinsey \& Company, McKinsey Global Institute. San Francisco: McKinsey \& Company. Retrieved February 2020, from https://www.mckinsey.com/featured-insights/ china/china-and-the-world-inside-the-dynamics-of-a-changing-relationship\#

National Development and Reform Commission. (2015). Vision and Actions on Jointly Building Silk Road Economic Belt and 21st-Century Maritime Silk Road. Beijing: Chinese Government.

$\mathrm{Pu}, \mathrm{X}$. (2016, December). One Belt, One Road: Visions and Challenges of China's Geoeconomic Strategy. 中國大陸研究, pp. 111-132.

State Council Information Office of the People's Republic of China. (2018). China's Arctic Policy. Pekin: Xinhua.

State Information Center. (2019, April 19). Belt and Road Portal. Retrieved November 2019, from https://eng.yidaiyilu.gov.cn/qwyw/rdxw/86301.htm

Subramanian, A. (2011, September). Renminbi Rules: The Conditional Imminence of the Reserve Currency Transition. Peterson Institute for International Economics (11-14), pp. 1-33. https://doi.org/10.2139/ssrn.1928138

Swaine, M. D. (2014). Chinese Views and Commentary on Periphery Diplomacy. China Leadership Monitor, 44.

U.S. Energy Information Administration. (2015, May 14). China Overview. U.S. Energy Information Administration, Independent Statistics \& Analysis. Washington, DC: U.S. Energy Information Administration. Retrieved February 2020, from https://www.eia.gov/ beta/international/analysis_includes/countries_long/China/china.pdf

US Department of State. (2017, January 20). U.S. Support for the New Silk Road. Diplomacy in Action. Retrieved November 2019, from https://2009-2017.state.gov/p/sca/ci/af/ newsilkroad/index.htm

Wuthnow, J. (2017). Chinese Perspectives on the Belt and Road Initiative: Strategic Rationales, Risks, and Implications. Center for Study of Chinese Military Affairs, Institute for National Strategic Studies. Washington D.C.: China Strategic Perspectives.

Yu, H. (2017). Motivation Behind China’s 'One Belt, One Road' Initiatives and Establishment of the Asian Infrastructure Investment Bank. Journal of Contemporary China, 26(105), pp. 353-368. https://doi.org/10.1080/10670564.2016.1245894

Zhang, Y., Zhang, M., Liu, Y. \& Nie, R. (2017, February). Enterprise investment, local government intervention and coal overcapacity: The case of China. Energy Policy, 101, pp. 162-169. https://doi.org/10.1016/j.enpol.2016.11.036 